University of California, Hastings College of the Law UC Hastings Scholarship Repository

1967

\title{
Conflict of Laws in Time: The Sweep of New Rules in Criminal Law
}

Roger J. Traynor

Follow this and additional works at: http://repository.uchastings.edu/traynor_scholarship_pub

\section{Recommended Citation}

Roger J. Traynor, Conflict of Laws in Time: The Sweep of New Rules in Criminal Law , 4 DUKE L. J. 713 (1967).

Available at: http://repository.uchastings.edu/traynor_scholarship_pub/29

This Article is brought to you for free and open access by the The Honorable Roger J. Traynor Collection at UC Hastings Scholarship Repository. It has been accepted for inclusion in Published Scholarship by an authorized administrator of UC Hastings Scholarship Repository. For more information, please contact marcusc@uchastings.edu. 
$7 d / 7$

36 



\title{
CONFLICT OF LAWS IN TIME: THE SWEEP OF NEW RULES IN CRIMINAL LAW
}

\author{
Roger J. Traynor
}

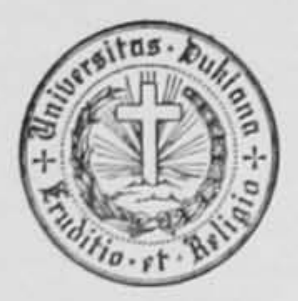

Reprinted from

列uke 政a Journal

Volume 1967, No. 4 



\title{
Thuke Zam Journal
}

\begin{tabular}{lll}
\hline Volume 1967 & AUGUST & Number 4 \\
\hline
\end{tabular}

\section{CONFLICT OF LAWS IN TIME: THE SWEEP OF NEW RULES IN CRIMINAL LA W*}

\author{
Roger J. TRAynor $\dagger$
}

W

E WHO JOIN to honor Brainerd Currie know the great gifts he brought to the law. Their benefits continue to multiply, for he was a man of genius whose work affords us insights for resolving some of our most troublesome legal problems. The very spirit of gentleness, he was also a man of such happy temperament, of such open heart and open mind, that he could have enlivened and enlightened any of the many mansions of the law. He was a superlative teacher and practitioner and writer. No scholar in the land commanded more respect from judges; he would have been a superlative judge. He was as profound in his understanding of the judicial process as in his criticism of particular decisions. He accepted as a fact of life the recurring gap between an ideal academic solution for a hypothetical problem and an optimum judicial decision in a kindred real controversy. His fine judicial sense is evident in all his work, whether he is explicating admiralty or procedure or conflict of laws. His Selected Essays on The Conflict of Laws, ${ }^{1}$ constituting one of his last gifts to the law, exemplify that judicial sense in a most complicated area.

Brainerd Currie's own way of celebrating the completion of one monumental task would be to turn his mind to a new one no less challenging. So it is fitting that in tribute to him, we venture upon such a problem today.

We have long recognized that the recurring head-on collisions

- Brainerd Currie Lecture delivered at the Duke Law School, May 11, 1967.

† Chief Justice, Supreme Court of California.

${ }^{1}$ Published in 1963. 
between laws of different jurisdictions warrant study as a special subject, which we call conflict of laws. That term of art encompasses what we might call wars in space. There are also recurring wars in time, within the confines of a single jurisdiction, between rules of law hallowed by usage and concepts ready to supplant them by reason of their superior fitness to govern contemporary problems. When such a concept emerges as a rule, should it operate only prospectively or also retroactively?

Much depends on whether the new rule appears in a statute or in a judicial decision, given the great difference between the legislative process and the judicial process. It is common knowledge that a legislature is free to make comprehensive changes in the law even if there is no thread of transition between new laws and old. A court has no such freedom. It works within the narrow confines of the case before it, deciding it in the main on the basis of precedent that it sometimes clarifies or amplifies. It overrules only rarely, when a precedent appears incurably defective or obsolete.

Given the freewheeling, forward-looking nature of legislation, it is appropriately given prospective application only, as a general rule admitting of few exceptions, a rule secured in many constitutions by an ex post facto clause as well as by clauses that compel due process or preclude impairment of contracts. Conversely, a judicial decision, even one that overrules a hitherto governing precedent, is appropriately given retroactive application, in the main a practice admitting of exceptions to preclude undue hardship upon those who have reasonably relied on the old precedent. ${ }^{2}$

A notable exception in our time to immediate retroactive application occurred in the case of Brown $v$. Board of Education. ${ }^{3}$ In declaring the state action in question unconstitutional, the court announced that its decision should be implemented with all deliberate speed. Recognizing the need for a two-way stretch in time to mitigate the problems of a transition that would involve millions of people, it reconciled the retroactivity usually attending a declaration of unconstitutionality with a phrase that enabled its new rule to take effect in slow motion.

In contrast, time has the aspect of an hour-glass in criminal law.

"See Traynor, The Well-Tempered Judicial Decision, - ArK. L. REv. - (1967), an address delivered at the University of Arkansas School of Law, May 9, 1967.

347 U.S. 483 (1954), rehearing on appropriate relief, 349 U.S. 294 (1955). 
In no other area of constitutional law is the problem of retroactive versus prospective application of such crucial importance. The time radius of the decision may directly affect the freedom or the very life of one accused or convicted of crime. An ex post facto clause hence exerts its most dramatic prohibition against retroactivity with regard to statutes that make conduct criminal that has not been criminal before. Though there is no comparable prohibition on a court, ${ }^{4}$ it usually also guards against any retroactive application of a decision that marks conduct as criminal for the first time.

In an unusual early case in North Carolina ${ }^{5}$ the court found its rationale for prospective application only in the defendant's reliance on an old interpretation of the law. He had been prosecuted under a statute prohibiting unauthorized removal of crops by a sharecropper. An earlier case $e^{\theta}$ involving the same statute had held that a sharecropper might defend by alleging the landlord's breach of contract as offsetting the amount of rent due. The court overruled the earlier decision, holding that the statute plainly meant that the crops were to remain on the land until all disputes between landlord and sharecropper were resolved and that any removal of the crops pending such settlement was a penal offense. The court went on to hold, however, that since the defendant might have acted on the advice of counsel in reliance on the earlier case, it would be unfair to deprive him of the defense authorized by that case.

Normally, however, reliance plays an inconsequential role, if any, in criminal cases, as in tort cases. The decisive factor is usually the injustice of retroactivity, dramatized by its penal consequences, as exemplified in the more recent case of James $v$. United States. ${ }^{7}$ At issue was the conviction of a defendant for "wilfully and knowingly" failing to pay an income tax on embezzled money. In an earlier case $^{8}$ the United States Supreme Court had held that embezzled funds were not taxable income. Six members of the court in the James case voted to overrule that decision, holding that embezzled funds were taxable income. A differently composed group of six justices, how-

4 E.g., Frank v. Mangum, 237 U.S. 309, 343-44 (1915); Ross v. Oregon, 227 U.S. 150, 161-64 (1913).

'State v. Bell, 136 N.C. 674 , 49 S.E. 163 (1904).

- State v. Neal, 129 N.C. 692, 40 S.E. 205 (1901).

7366 U.S. 213 (1961).

${ }^{8}$ Commissioner v. Wilcox, 327 U.S. 404 (1946); see Comment, Prospective Overruling and Retroactive Application in the Federal Courts, 71 YALE L.J. 907, 924 (1962). 
ever, voted not to convict James: three on the ground that the old rule still prevailed when he failed to pay the tax, and hence made it impossible to prove wilful evasion; and three on the ground that the old rule was correct. Accordingly, there was no retroactive application of the new interpretation of the tax statute. It is hardly persuasive that James failed to report his income in reliance on the old rule; there was an equal likelihood that he concealed his income to avoid prosecution for embezzlement. Though no element of reliance is present, the James decision is responsive to the principle that the retroactive operation of a rule imposing or expanding criminal liability would be inherently unjust.

In a few jurisdictions, courts may convict persons of crimes even though the conduct charged against them is nowhere specified by statute as criminal. These jurisdictions punish so-called "common law offenses," acts that fall expressly or by analogy within some common law decision, however ancient and obscure. ${ }^{9}$ Predominantly they are acts characterized as immoral, obscene, or in some such wise offensive. Thus a 1939 Maine decision ${ }^{10}$ convicted a defendant of disposing of a human body by burning it in a household furnace. The court stated that the common law gives expression to people's changing customs and sentiments, and that acts which are highly indecent and contra bonos mores are therefore crimes.

Some jurisdictions penalize such acts under very general statutes covering conduct against public morality, or under conspiracy provisions penalizing agreements to carry on lawful acts in an unlawful manner or to injure or corrupt the public good. In a 1932 Oregon case, Multnomah County Fair Association v. Langley, ${ }^{11}$ the court enforced a broad criminal nuisance statute directed against "any act which grossly injures the person or property of another, or which grossly disturbs the public peace or health, or which openly outrages public decency and is injurious to public morals ...."12 With comparable sweep, a Kentucky court in 1933, in Commonwealth $v$.

- See 21 Am. Jur. 2d Criminal Law $\$ 10$ (1965).

${ }^{10}$ State v. Bradbury, 136 Me. 347, 9 A.2d 657 (1939).

${ }_{11} 140$ Ore. 172, 13 P.2d 354 (1932).

12 Ore. Code $\$ 14-722$ (1930). An analogous provision still exists. ORE. REv. Stat. \$161.310 (1953). See State v. Elliott, 204 Ore, 460, 277 P.2d 754 (1954), cert. denied, 349 U.S. 929 (1955) (upholding a conviction under the act for operating an abortion clinic over a challenge of unconstitutional vagueness resting on the Fourteenth Amendment's due process clause); State v. Dewey, 206 Ore. 496, 292 P.2d 799 (1956) (same). 
Donoghue, ${ }^{13}$ held an agreement to commit usury to be a criminal conspiracy, although usury itself was legal.

These so-called "morals offenses" create refractory problems of retroactivity. Usually a defendant cannot divine that a decision will make criminal the very conduct he is engaged in. Retroactivity in the common law of crime, attended by penal sanctions, may be particularly oppressive when the defendant's conduct lacked any element of mens rea. It is reasoning in a circle to attribute consciousness of wrongdoing to a defendant on the sole ground that since his conduct is now adjudged offensive to widely held community standards of basic morality, its criminal nature should have been known to him.

It may avail little to a defendant to exercise his right to a jury trial when charged with an allegedly criminal offense, not against a person or property, but against the abstraction of public morality. Given that indeterminate abstraction, twelve randomly selected jurymen have the same large discretion as a trial judge to adjudge conduct criminal that has nowhere in law been so specified.

Judicial discretion, whether of trial judge or jury, is also an indeterminate abstraction elusive of constitutional limitation. An appellate court is wary of countermanding the discretionary judgment of the triers of fact unless there is patent abuse of their discretion, a phrase whose own vagueness matches the abstraction to which it relates. Thus two indeterminate abstractions, one encompassing conduct allegedly criminally offensive and the other encompassing judicial discretion to adjudge conduct as criminally offensive, interact to create a vicious circle. It might better be described as a vicious vortex, into whose vacuum every person risks being drawn. It is a very present danger, an omnipresent one, whose sinister aspects ironically are camouflaged by the ceremonious judicial process through which it moves. The courtroom, whose judge and jury are regarded as the intent guardians of fair procedure, lends itself to a vitiation of that procedure whenever the guardians freely invoke their discretion to stigmatize conduct as criminal and to apply the punishment retroactively.

Transcending the injury to the one thus condemned by the erratic operation of judicial fiat is the oppressive censorship it threatens to all others. Even if the threat does not materialize immediately or on

13 250 Ky. 343, 63 S.W.2d 3 (1938). 
a large scale, it exerts a damaging influence against the diversity of custom and thought that characterizes the open pluralistic society. Those aware of the threat tend to stifle themselves, to fit their conduct to prevailing patterns, to speak only the speech of the sickly sweet lest they offend a majority well able to mobilize its deadly innocence against any questioning words.

As for those who are not aware of any threat, or are not in fear of it, they risk more imminent injury. The first among them to be criminally prosecuted may be those whose offenses are so close to specified crimes as to seem properly punishable. But each such punishment broadens the area of prosecution and the number of those who may be caught in it. No one can forget that in our own time, in purportedly civilized countries, millions have thus been caught who have committed no greater offense than to be themselves.

In the recent case of Ginzburg $v$. United States, ${ }^{14}$ three of the four dissenting justices viewed the majority decision as a retroactive expansion of criminal liability for conduct not hitherto specified as a crime. The decision, interpreting a federal statute on obscenity, ${ }^{15}$ adjudged defendants guilty of mailing obscene matter. Even though the majority opinion assumed that the magazines actually mailed were not obscene, it attributed to the mailing an obscenity derived from the manner in which they were advertised and prepared for mailing. Thus it greatly broadened the sweep of an already sweeping statute. Something new has been added to the normal question under such a statute: What was defendant doing? It is now in order in the courtroom also to ask: What did he think he was doing?

With this subtle interpolation of motive in a statute on its face concerned only with obscene matter, whatever that vague term may mean, what are the limits of the growth possibilities of obscenity as a crime? Those who prosecute for obscenity need not prove that the defendant was murdering the English language or even roughing it up. The crucial question is not only how the defendant conducts himself, but whether his motive was pure. Evil to him who evil thinks.

The pudding, of course, is in the proof. Since the proof of evil motive is now called for by the statute, Ginzburg could become an endless pudding, spilling little ones into every corner of the land. It

14383 U.S. 463, rehearing denied, 384 U.S. 934 (1966).

${ }^{15} 18$ U.S.C. $\S 1461$ (1964). 
is not quieting to envisage the many custodians who now stand ready to put in their plums, and pull out their thumbs, and say: What a good boy am I.

Our plum puddings are not more spectacular than those of the mother country. The Ginzburg case finds a foggy peer in the British case of Shaw $v$. Director of Public Prosecutions, ${ }^{16}$ highlighting the durability of the conspiracy net in common law. The defendant published a "Ladies Directory," listing the names and addresses of prostitutes. He was convicted of publishing an obscene booklet under the Obscene Publications Act of 1959, superseding common law rules hitherto governing obscene publication. He was also convicted of conspiracy to corrupt public morals, an offense declared by the trial judge to be a common law misdemeanor. The Court of Criminal Appeals affirmed the conviction and the House of Lords reaffirmed. In the reaffirmation, the majority adhered to a view of the court as custos morum of the people's morality, as they say in English, or as the Latins might say, the moral custodian. There was an oddly archaic sound to the purportedly forward-looking speech of several that equated the conspiracy conviction with the right and duty of the court to keep the common law of crimes responsive to current public policy. Thus Viscount Simonds declared that "The law must be related to the changing standards of life, not yielding to every shifting impulse of the popular will but having regard to fundamental assessments of human values and the purposes of society." 17

What of decisions that contract criminal liability? In such a case retroactivity would be beneficent rather than harsh. Contraction of criminal liability can take various forms: a court declares a criminal statute unconstitutional; a legislature repeals a criminal statute expressly or by implication, or repeals a statute and later substantially re-enacts it; or a court reinterprets a criminal statute to the advantage of defendants, either by narrowing the scope of the statute or by articulating new defenses to it. These examples each warrant examination.

In the simplest example, when a court declares a criminal statute unconstitutional, the invariable rule is that all defendants previously convicted under that statute are entitled to release, whether their convictions are final or not. This rule is at least as old as the 1879

${ }^{10}[1961] 2$ Weekly L.R. 897 (H.L.).

${ }^{17} \mathrm{Id}$. at 917. 
case of Ex parte Siebold, ${ }^{18}$ in which the Supreme Court declared that a conviction under an unconstitutional statute is void and therefore subject to collateral attack.

As for legislative repeal of a criminal statute, it was normally attended at common law by automatic abatement of all prosecutions under it, on the presumption that the legislature intended repeal to operate as a pardon for past acts. ${ }^{19}$ Abatement did not extend, however, to final convictions, probably because of the originally limited nature of habeas corpus and the general unavailability of remedies via collateral attack in early Anglo-American criminal law. Moreover, there was no abatement when the legislature clearly could not have intended a pardon, as when the new statute merely affected the manner of punishment, or merely took over the field from the old, or substantially re-enacted the old, as in the case of codifications, consolidations, or revisions.

The problems of legislative repeal are exemplified in two modern cases decided by the United States Supreme Court, the "sit-in" cases of Bell v. Maryland ${ }^{20}$ and Hamm v. City of Rock Hill. ${ }^{21}$ In Bell $v$. Maryland, "sit-in" demonstrators had been convicted of criminal trespass. While their case was pending on writ of certiorari in the Supreme Court, the Maryland legislature enacted "public accommodation" laws that gave them a right to be in public restaurants and therefore probably rendered their supposed trespass noncriminal. Like many states, Maryland had a "saving clause" to avoid the common law rule of automatic abatement on repeal, but there was some doubt whether the clause applied to petitioners' convictions. The Supreme Court therefore reversed and remanded to the Maryland court to determine whether under state law the prosecutions against petitioners might be deemed abated under the new statute. The Maryland Supreme Court affirmed their convictions. ${ }^{22}$

In contrast, in Hamm v. City of Rock Hill, ${ }^{23}$ petitioners' "sit-in" conduct had been rendered noncriminal by a federal statute, the

${ }^{18} 100$ U.S. $371,376-77$.

${ }^{10}$ See Sekt v. Justice's Court, 26 Cal. 2d 297, 304-05, 159 P.2d 17, 21, cert. denied, 326 U.S. 756 (1945).

${ }^{20} 378$ U.S. 226 (1964).

21379 U.S. 306 (1964). In addition, see Blow v. North Carolina, 379 U.S. 684 (1965) (per curiam).

22 Bell v. State, 236 Md. 356, 204 A.2d 54 (1964).

2s 379 U.S. 306 (1964). 
1964 Civil Rights Act. ${ }^{24}$ The United States Supreme Court held that the convictions, still on direct review when the Civil Rights Act was enacted, were abated by the federal statute rendering their conduct noncriminal.

An analogous situation arises when a court reinterprets a criminal statute so as to narrow it, thus essentially repealing the statute as to some defendants. In this area the decision in Warring $v$. Colpoys ${ }^{25}$ has aroused much criticism. A defendant had been convicted in 1939 under a federal contempt statute that punished conduct in the presence of the court or "so near thereto" as to obstruct the administration of justice. At the time of defendant's conviction case law required a causal rather than a geographic link between the offending conduct and the offended court. ${ }^{26}$ Two years after Warring's conviction, however, the Supreme Court reversed itself, holding that the contempt statute required geographic proximity between conduct and court. ${ }^{27}$ Under this new interpretation Warring might not have been guilty of criminal contempt, but the court denied habeas corpus.

A comparable decision has recently been rendered by the Pennsylvania Supreme Court, in Commonwealth ex rel. Almeida v. Rundle. ${ }^{28}$ Petitioner had been convicted of first degree felony-murder in the course of robbery. His victim, a policeman, had actually been killed by a bullet from the gun of a fellow policeman during the fracas of the robbery. Long after petitioner's conviction the Pennsylvania court, in Commonwealth $v$. Redline, ${ }^{29}$ adopted a new theory of felony-murder that could have removed his crime from that category. The Pennsylvania court, however, denied habeas corpus, holding that criminal convictions are to be governed by the law in force at the time of the conviction. The United States Supreme Court denied certiorari. $^{30}$

Sometimes there are legislative changes in punishment. They are usually subject to a rule precluding retroactive application to defendants whose convictions have become final. Such a rule is of course inevitable as to increases in punishment, whose retroactive

${ }^{24} 78$ Stat. $243-44,42$ U.S.C. $\$ 2000$ a (1964).

${ }^{25} 122$ F.2d 642 (D.C. Cir.), cert. denied, 314 U.S. 678 (1941), discussed in Comment, 71 YALE L.J. 907, 940 (1962).

${ }^{20}$ See Toledo Newspaper Co. v. United States, 247 U.S. 402 (1918).

${ }^{27}$ See Nye v. United States, 313 U.S. 33 (1941).

${ }_{28} 409$ Pa. 460, 187 A.2d 266, cert. denied, 374 U.S. 815 (1963).

20 391 Pa. 486, 137 A.2d 472 (1958).

so 374 U.S. 815 (1963). 
application would not be constitutionally permissible under the usual ex post facto clause. As to statutes mitigating punishment, however, there is no constitutional barrier to retroactive application, and there are compelling arguments in its favor. Once the legislature adopts a lesser penalty as adequate, the retention of a harsher penalty no longer serves any legitimate penological goal. Hence we declared in California, in In re Estrada, ${ }^{31}$ that when a criminal statute is amended to mitigate punishment after the prohibited act was committed but before a final judgment of conviction is entered, the amended statute governs.

The rationale of Estrada would seem to be equally applicable to a defendant whose judgment of conviction has become final. An early case decided otherwise. In 1831, in State $v$. Addington, ${ }^{32}$ petitioner was convicted of horse stealing and sentenced to death. Meanwhile an amendment to the penal statutes reduced the punishment to whipping, imprisonment, and a fine. The court refused to apply the lesser punishment retroactively on the ground that it loses all power over a case once a judgment becomes final. It nevertheless recognized the harshness of this rule and strongly recommended executive clemency.

Modern decisions extending the scope of habeas corpus have militated against such unbending finality of judgments in criminal law. Moreover, in states such as California, a system of indeterminate sentencing serves to keep a petitioner's case open. The Adult Authority may redetermine his sentence at any point up to maximum term. ${ }^{33}$

One can roughly generalize from the foregoing survey that the traditional defenses against retroactivity of new rules of criminal law that would adversely affect a defendant are still firmly entrenched. There may be a trend, in nonconstitutional cases, toward retroactivity of new rules that would beneficently affect a defendant. The maverick domain of vague offenses against public morality is so unruly as to defy prediction. If skirts continue to grow shorter, however, and rules of morality longer, everyone may have to become his sister's keeper to keep her out of the clutches of the law as it makes increasingly proper advances.

${ }^{31} 63$ Cal. 2d 740, 48 Cal. Rptr. 172, 408 P.2d 948 (1965). See also People v. One 1953 Buick, 57 Cal. 2d 358, 19 Cal. Rptr. 488, 369 P.2d 16 (1962).

s2 11 S.C. 516 (1831).

${ }^{33}$ CAL. Pen. Code $\$ \$ 1168,3020,3023,5077$. 
We now turn to the cluster of recently formulated constitutional rules relating to criminal detection, detention, and trial. ${ }^{34}$ They have aroused national attention, engendering bitter debate between the turbid woe-cryers who denounce the rules as criminal-coddling and the turgid enthusiasts who hail them as bulwarks against oppression. Our task is to get down to cases.

Their common problem is the integrity of the fact-finding process from its inception in criminal detection through detention and trial. They begin with the Bill of Rights as applied to the states via the Fourteenth Amendment, an application that has gained momentum since the propelling concept of ordered liberty enunciated in Palko v. Connecticut. ${ }^{35}$ They culminate in rules that would be beneficent to the defendant if retroactively applied.

It would seem that since the new rules have a common ground in the concept of ordered liberty, defined as proceeding from the conscience of mankind, they would by definition be of universal application. Hence they would reach backward in time as well as forward, to apply retroactively even though they might upset final judgments. Thus the United States Supreme Court declared in 1963 that "conventional notions of finality of litigation have no place where life or liberty is at stake and infringement of constitutional rights is alleged." ${ }^{36}$

Since that declaration the Court has applied some but not all of the beneficent rules retroactively. Why not all? The question is basic, compelling us to seek out the considerations that in some cases dictated prospective operation only.

There is an opening clue, which in the final analysis fails to yield a complete explanation. We find that in some of the cases the preoccupation is to deter oppressive police practices or prosecution procedures that constitute a long-range danger to the community. In others the preoccupation is to guard against convicting the innocent. The difference is only one of emphasis, on one side of the coin or the other of the integrity of the fact-finding process, insofar

"See Traynor, The Devils of Due Process in Criminal Detection, Detention, and Trial, 33 U. CHI. L. Rev. 657 (1966), Twenty-third Annuai Benjamin N. Cardozo Lecture delivered at the Association of the Bar of the City of New York on April 19, 1966.

s5 302 U.S. 319 (1937). Although the members of the Supreme Court may agree that a particular right is fundamental and therefore within the scope of the Fourteenth Amendment, their views differ as to how that result should be reached. See Henkin, "Selective Incorporation" in the Fourteenth Amendment, 73 YALE L.J. 74 (1963).

so Sanders v. United States, 373 U.S. 1, 8 (1963). 
as we view the cases solely in their abstract relation to ordered liberty.

The difference may widen, however, if we also weigh the immediate practical effects of retroactive or prospective operation of a beneficent new rule. There is a graphic illustration in Mapp v. Ohio, ${ }^{37}$ which extended the Fourth Amendment exclusionary rule to the states through the ordered liberty route of the Fourteenth Amendment. The objective of the Mapp rule was to deter unreasonable searches and seizures by excluding the resulting evidence at the trial. There was no question as to the reliability of the evidence and hence no corresponding danger of convicting the innocent.

Mapp generated concern throughout the country as to whether it would apply retroactively not only to cases on appeal but also to final judgments. In my own state I confronted the problem in a concurring opinion in In re Harris. ${ }^{38}$ Some years earlier, in People v. Cahan,$^{39}$ California had anticipated the Mapp decision by adopting the exclusionary rule. Instead of making it a rule of constitutional dimension, however, we made it a rule of evidence; hence its violation afforded no ground for collateral attack on final judgments. It was perforce turned into a constitutional rule by Mapp, and the question arose as to whether it must now apply retroactively. In deciding against retroactivity, in In re Harris, I noted that the purpose of the exclusionary rule is not to protect the guilty but to deter unconstitutional police practices. It seems clear that "Deterrence would be served but little more and at exorbitant cost by affording the weapon of collateral attack to those defendants who were convicted before the adoption of any exclusionary rule and hence had no way of challenging the admissibility of the evidence. To begin with, their cases are history, and they should not now be given the power to rewrite it. To place at the disposition of the guilty an extraordinary remedy designed to insure the protection of the innocent would be to invite needless disruption in the administration of justice." 40

It must be remembered that

The most telling reason for collateral attack on judgments of conviction is that it operates to eliminate the risk of convicting the innocent. Such a risk attends any conviction ensuing from the witting use of perjured testimony, the suppression of evidence, an

${ }^{37} 367$ U.S. 643 (1961).

ss 56 Cal. 2d 879, 880, 16 Cal. Rptr. 889, 890, 366 P.2d 305, 306 (1961).

so 44 Cal. 2d 434, 282 P.2d 905 (1955).

${ }^{40}$ Traynor, Mapp v. Ohio at Large in the Fifty States, 1962 Duke L.J. 319, 341. 
involuntary confession, the denial of an opportunity to present a defense, and the denial of the right to counsel. A comparable risk arises upon a failure to provide an indigent defendant with a trial transcript necessary to perfect his appeal.

The most telling distinction of a defendant convicted on evidence resulting from an unreasonable search or seizure is that he is clearly guilty. It is not the purpose of the exclusionary rule to protect the guilty. Its purpose of deterring lawless law enforcement will be amply served in any state ... by affording defendants an orderly procedure for challenging the admissibility of the evidence at or before trial and on appeal. ${ }^{41}$

The views set forth in the Harris case gained strength when the United States Supreme Court in Linkletter v. Walker ${ }^{42}$ decided against any retroactive application of $M a p p$ that would upset final judgments that became final before $M a p p$. It invoked as a test "no likelihood of unreliability" 43 in the fact-finding process. Given reliability, the court was free to weigh official reliance and the advantages of orderly transition against the usual factors in favor of retroactive application of judicial rules.

The Fourth Amendment cases demonstrated that rules of ordered liberty might operate with less than absolute retroactivity, however absolute a ring they had in the abstract. New problems of retroactivity were soon to arise in the now famous cases that have worked basic changes in criminal procedure through the usual ordered liberty route of the Fourteenth Amendment. When Malloy v. Hogan ${ }^{44}$ extended the Fifth Amendment to the states, it cast a formidable shadow on a rule followed in six states allowing comment on the defendant's failure to take the stand to explain or deny facts when he could reasonably be expected to do so. ${ }^{45}$ Nevertheless, we still felt free in California to uphold such a rule in People v. Modesto, ${ }^{46}$ reaffirming the validity of a state constitutional provision that allowed restricted comment on the silence of a defendant in a criminal trial. ${ }^{47}$

Thereafter, the United States Supreme Court declared the rule unconstitutional in Griffin $v$. California. ${ }^{48}$ It relied at least in part

\footnotetext{
${ }^{41} I d$. at $340-41$ (citations omitted).

42381 U.S. 618 (1965).

${ }^{43} \mathrm{Id}$. at 638 .

« 378 U.S. 1 (1964).

45 See Griffin v. California, 380 U.S. 609, 611-12 n.3 (1965).

${ }^{40} 62$ Cal. 2d 436, 42 Cal. Rptr. 417, 398 P.2d 753 (1965).

${ }^{47}$ Cal. Const., art. I, § 13; see Cal. Pen. Code, § 1323.

48380 U.S. 609 (1965).
} 
on the theory that the comment rule impaired the reliability of the fact-finding process. Given this relation back to the Linkletter test, it seemed logical that the Grifin rule would be given the retroactive application adumbrated in the Linkletter test. In the subsequent case of Tehan $v$. United States ex rel. Shott, ${ }^{49}$ however, the court considered the appropriateness of retroactivity under a new test: Was there a "clear danger of convicting the innocent" unless there were retroactive application of the beneficent new rule?50 This language is not a restatement on all fours with the Linkletter test: Would there be "no likelihood of unreliability," in the fact-finding process, and hence no likelihood of convicting the innocent if there were no retroactive application?

The Supreme Court itself was cognizant in Johnson $v$. New Jerse $^{51}$ that the Tehan test had a narrower range of retroactive application than the Linkletter test when it stated:

... we denied retroactive application to Griffin $v$. California ... despite the fact that comment on the failure to testify may sometimes mislead the jury concerning the reasons why the defendant has refused to take the witness stand. We are thus concerned with a question of probabilities and must take account, among other factors, of the extent to which other safeguards are available to protect the integrity of the truth-determining process at trial. ${ }^{52}$

This restatement of the Tehan rule indicates the Court's disposition toward weighing the reliability of the fact-finding process in terms of "probabilities" rather than automatically according a defendant the benefit of retroactive application unless the probabilities are equivalent to "no likelihood of unreliability." The Court thus came to a reckoning with the repercussions of the Griffin rule, which enabled defendants to invoke the Fifth Amendment with doublebarreled effect. A defendant who testified could plead that he did so under compulsion to avoid comment. A defendant who remained silent could plead that he did so at the cost of such comment. Conceivably some might plead that they had sought to avoid comment on a serious charge by pleading guilty to a lesser offense.

It was no easy matter for the Court, after it had taken its stand in

${ }^{40} 382$ U.S. 406 (1966); see also In re Gaines, 63 Cal. 2d 234, 45 Cal. Rptr. 865, 404 P.2d 473 (1965).

${ }^{50}$ Id. at 416 .

${ }^{51} 384$ U.S. 719 (1966).

${ }^{52}$ Id. at 729 . 
Griffin against comment, to decide in Tehan against the retroactivity of the Griffin rule. The Tehan decision involved some decompression in the mold of the self-incrimination clause of the Fifth Amendment. Whatever the bends of decompression, they were the inevitable sequence of a drastic change to preclude its becoming so hard and fast a rule as to wreak havoc with final judgments in the jurisdictions that had allowed comment. ${ }^{53}$

Once the Court undertook such adjustment, it gained freedom to decide against any retroactive application of the new rules on police interrogation announced in the historic cases of Escobedo v. Illinois ${ }^{54}$ and Miranda $v$. Arizona ${ }^{55}$ It came as a surprise, however, that when it did so in Johnson $v$. New Jersey, ${ }^{56}$ it specified a cutoff date that is baffling except in terms of expediency. Even though the case arose on habeas corpus and hence could have been governed by the Linkletter and Tehan tests, the Court chose to reject the final judgment cutoff. $^{57}$ It held instead "that Escobedo affects only those cases in which the trial began after June 22, 1964, the date of that decision. We hold further," the Court stated, "that Miranda applies only to

${ }^{68}$ The implications of Tehan are explored by the dissenters in Spencer v. Texas, 385 U.S. 554 (1967). The majority in that case determined that it did not violate the due process clause to inform the jury of prior convictions during the trial. The four dissenters took the view that there was no rational basis in this case for admitting such evidence prior to a finding of guilt and that to do so was therefore a denial of due process. The dissenters disagreed, however, on the extent to which the admission of evidence of prior convictions affected the reliability of the fact-finding process. Justices Douglas and Brennan concluded, apparently on the basis of the Linkletter test, that the fact-finding process was sufficiently impaired to compel retroactive application. 385 U.S. at 587. Chief Justice Warren and Justice Fortas, invoking the Tehan test, concluded that Spencer did not differ materially from Griffin and that the reasonable reliance of Texas officials on prior law militated against retrocative application. 385 U.S. at 583-87. Their disposition to give more weight to official reliance than to the possibility of convicting the innocent may reflect an effort to gain acceptance of the minority view via a rationale that would foster its prospective application only.

64378 U.S. 478 (1964).

ธ5 384 U.S. 436 (1966).

вo 384 U.S. 719 (1966).

${ }_{57}$ "By final we mean where the judgment of conviction was rendered, the availability of appeal exhausted, and the time for petition for certiorari had elapsed . . ." Linkletter v. Walker, 381 U.S. 618, 622 n.5 (1965). The California Supreme Court applied this rule in People v. Polk, 63 Cal. 2d 443, 47 Cal. Rptr. 1, 406 P.2d 641 (1965), cert. denied, 384 U.S. 1010 (1966). Judgment on the issue of guilt against defendants Polk and Gregg was affirmed on March 31, 1964. Since Escobedo was decided on June 22, 1964, an application for certiorari could have been filed within the 90-day period beginning on March 31. Although none was filed, the defendants were given the benefit of the Escobedo rules because the California Supreme Court had decided on the final-judgment cutoff for Escobedo. In re Lopez, 62 Cal. 2d 368, 42 Cal. Rptr. 188, 398 P.2d 380 (1965), cert. denied, 384 U.S. 1016 (1966). 
cases in which the trial began after the date of our decision one week ago." 58

The Court made this choice between the two alternatives it postulated: whether the rules "shall affect cases still on direct appeal when they were decided or whether their application shall commence with trials begun after the decisions were announced."59 Apparently it departed from the final judgment cutoff because it would have compelled the Court to apply the Escobedo and Miranda rules to cases then pending on appeal, something it did not wish to undertake. ${ }^{60}$

88384 U.S. at 721 .

so 384 U.S. at 732 .

${ }^{\circ 0}$ In conjunction with fixing the prospective limitation line in Johnson, to ease the jolt of transition to Escobedo and Miranda rules, the Court in Miranda and Johnson narrowly construed the holding of Escobedo to minimize its impact.

The courts that had faithfully followed Escobedo and reversed judgments of conviction accordingly, now learned that they need not have done so. The courts that had resisted Escobedo now learned that it was possible to resist a Supreme Court decision with impunity. See The Supreme Court, 1965 Term, 80 Harv. L. REv. 91, 139 (1966),

In People v. Dorado, 62 Cal. 2d 338, 42 Cal. Rptr. 169, 398 P.2d 361, cert. denied, 381 U.S. 937, 946 (1965) we felt bound to decide Dorado "in conformity with the decisions of the Supreme Court of the United States. That court having declared the content of a constitutional right, it is our function to enforce it in situations wherever it logically applied." Id. at 357, 42 Cal. Rptr. at 181, 398 P.2d at 373.

The Dorado case presented a factual situation squarely within the holding of Escobedo except for one factor: Dorado had failed to request counsel. Id. at 347,42 Cal. Rptr. at 175, 398 P.2d at 367. It was settled law at the time of Escobedo and Dorado, however, that the right to counsel did not depend on whether the accused had retained or requested counsel. Id. at 350-51, 42 Cal. Rptr. at 176, 398 P.2d at 368; see Escobedo v. Illinois, 378 U.S. 478, 495 (1964) (dissenting opinion); see also People v. Roberts, 63 Cal. 2d 84, 93, 45 Cal. Rptr. 155, 161, 403 P.2d 411, 417 (1965), in which the knowledgeable defendant, who had prior encounters with the police, requested counsel during the police interrogation whereas codefendant Coleman, unversed in such matters, failed to make such a request. It seemed inconceivable that in such a case the Escobedo rule would operate for one defendant, but not for the other. It could hardly be that a reprieve from a rendezvous with the death penalty would turn on the incantation of magic words.

The clarification in Miranda supported the correctness of Dorado. One week after Miranda, however, the Court limited Escobedo to its specific narrow holding (Johnson v. New Jersey, 384 U.S. 719, 734 (1966)) and characterized Dorado as anticipating Miranda, but as not "clearly foreshadowed" by Escobedo.

"[T] he refusal to apply Miranda to cases decided after Escobedo was handed down will tend to frustrate the purposes of constitutional adjudication broadly conceived. It will surely encourage law enforcement officials and lower courts to take a restrictive view of constitutional decisions which they consider distasteful, since they will be secure in the knowledge that convictions obtained by interpreting ambiguous constitutional rules favorably to themselves will not be reversed. No bona fide reading of the reasoning of Escobedo could have led to a construction much short of that advanced in Miranda." The Supreme Court, 1965 Term, supra, at 139. See also the reference to the New Jersey Supreme Court's actions in Comment, 64 MrCH. L. REv. 832,850 n.113 (1966). 
The Court's choice is hardly ideal, whatever its expediency. ${ }^{61}$ It meant that no cases would be reversed in consequence of the new rule during the given transitional period. It is difficult to reconcile the Court's own references to immutable principles and to binding guarantees newly discovered in the century-old Fourteenth Amendment with a declaration that they are to have no effect until June 22, 1964.

Although this technique precludes the reversal of trial courts, it places other appellate courts in an awkward position. The Constitution is construed as clearly prohibiting a state from using improperly obtained confessions; but the constitutional prohibition does not govern all the cases an appellate court might have before it. Under the final judgment cutoff a court could refuse to hear issues raised collaterally. Under Johnson, however, it must hear the Escobedo-Miranda issues if they are raised. If the defendant unfortunately had a trial that started on the wrong day, the court then confronts an unhappy choice. It must either deny such a defendant the benefit of a constitutional rule, as the Supreme Court itself has done, or accord him the benefit of the rule, as the Supreme Court itself has not undertaken to do.

From among the cases pending that raised the Miranda issue, the Supreme Court applied the Miranda rule to only four and denied certiorari in the remaining 129 cases. $^{62}$ The denial of relief from imprisonment or death on the basis of an arbitrary date raises a grave question of equal protection. If those whose cases were pending were reliably found guilty and hence did not deserve relief, the inequity remains that a few among them nonetheless did receive relief. ${ }^{63}$

So glaring an inequity is not dispelled by a rationalization that the lucky few were only incidental beneficiaries of a technique designed to avert wholesale reversals. For better or worse, the technique of the Johnson case is on the books, open to further use. We

${ }^{\circ 1}$ Johnson may not have been the most desirable solution even in terms of expediency. An interrogation-date rule would have the advantage of equal applicability to all defendants as to whom the state acted improperly and would still not penalize the state for good faith conduct that was legal when it occurred. See State v. Gannites, 221 A.2d 620, 623-24 (R.I. 1966).

${ }^{\circ 2}$ See The Supreme Court, 1965 Term, supra note 60, at 141 \& n.37.

'See Currier, Time and Change in Judge-Made Law: Prospective Overruling, 51 VA. L. REv. 201-05, 261-72 (1965); H. Schwartz, Retroactivity, Reliability and Due Process: A Reply to Professor Mishkin, 33 U. CHI. L. REv. 719, 733, 764 (1966). 
can anticipate that it will be urged by advocates seeking to make palatable a proposed change in criminal law or for that matter in civil law. Thus a technique envisaged as an interim expedient may invite carelessness, for it can be used to temporize whenever a new rule is announced too precipitously for consistent and equitable application. ${ }^{64}$

If there is to be more of such temporizing, who can say where it will end? What is to stop Congress from stepping in with its own timepiece to determine at what hour the shadow of any new judicial rule should fall? Once it does, are there any limits on its authority to tell the time?

Comparable questions as to the state legislature arose in California in sequence of a judicial decision in a mundane field. The Supreme Court of California overruled an old precedent on state constitutional grounds that had governed the taxation of private leaseholds in tax-exempt public property. ${ }^{65}$ It applied its new rule retroactively after weighing the considerations pro and con. Then the legislature came into the picture and after weighing the considerations on its own scales retimed the new rule so that it would not apply retroactively to leases negotiated prior to its adoption. Was this legislative retiming of a constitutional rule constitutional? When it was put to a judicial test in Forster Shipbuilding Co.v. County of Los Angeles ${ }^{66}$ our court upheld it, stating: "[T]emporary application of the rule of an overruled case may be prescribed by appropriate legislation as well as by judicial decision, for the Legislature is no less competent than the court to evaluate the hardships involved and decide whether considerations of fairness and public policy warrant the granting of relief." 67

Given faint echoes of Marbury v. Madison ${ }^{68}$ in this modern case, it bears noting that the court itself did not make retroactivity a constitutional mandate. It viewed retroactivity as a problem turning on considerations of fairness and policy. This multiparous problem begets many such considerations, and they may be as much the concern of the legislature as of the court.

Cases may of course arise in which retroactivity is a constitutional

*4 See Friendly, Benchmarks, 266-84 (1967).

${ }^{\circ}$ De Luz Homes, Inc. v. County of San Diego, 45 Cal. 2d 546, 290 P.2d 544 (1955).

o0 54 Cal. 2d 450, 353 P.2d 736 (1960).

${ }^{\circ}$ Id. at 459, 353 P.2d at 741 .

${ }^{6} 5$ U.S. (1 Cranch) 137 (1803). 
imperative, and the court specifies it as such. In such a case a legislature would be bound by the retroactivity of the rule as much as by the rule itself as the last word.

Our foremost legislature is of course Congress. In cases in which retroactivity is not a constitutional imperative, it would seem that Congress has freedom to make a Supreme Court rule prospective only, on grounds of fairness or policy, even though the court itself made the rule fully or partially retroactive.

It is relatively simple to consider the possibilities of setting a judicial rule by legislative time in terms of a state legislature in relation to a state's highest court or of Congress in relation to the United States Supreme Court. It is confoundedly relative to consider such possibilities in terms of a state legislature in relation to the United States Supreme Court, assuming that Congress remains silent. That query we leave to another day, preferably a long one. ${ }^{69}$

The prospects are that it will be sooner than later that we shall be confronting new problems in the relativity of time. ${ }^{70}$ We shall be fortunate indeed if a scholar appears to unriddle them with a genius akin to that of Brainerd Currie.

"Traynor, The Well-Tempered Judicial Decision, - ARK. L. REv. - (1967).

${ }^{70} \mathrm{~A}$ bill (H.R. 2508, §2) now pending in the United States Senate would postpone until 1972 the full impact of the decision that congressional districts be apportioned according to the one man, one vote principle. Wesberry v. Sanders, 376 U.S. 1, 8, 18 (concurring opinion) (1964). It would permit congressional elections to be held even in states having a $35 \%$ disparity among districts. Since the United States Supreme Court itself authorized federal courts to weigh equitable considerations in timing the redistricting in the states (Reynolds v. Sims, 377 U.S. 533, 585 (1964)), it would seem that Congress also can weigh those considerations and fix the timing of the redistricting. 